\title{
Climate Index for District Heating System
}

\author{
Ieva PAKERE ${ }^{1 *}$, Dace LAUKA ${ }^{2}$, Kristiāna DOLGE $^{3}$, Valdis VITOLINS $^{4}$, \\ Ilze POLIKARPOVA ${ }^{5}$, Stefan HOLLER ${ }^{6}$, Dagnija BLUMBERGA ${ }^{7}$ \\ ${ }^{1-5,7}$ Institute of Energy Systems and Environment, Riga Technical University, Azenes iela 12/1, \\ Riga, LV-1048, Latvia \\ ${ }^{6}$ HAWK Hildesheim/Holzminden/Göttingen University of Applied Sciences and Arts, Germany
}

\begin{abstract}
District heating (DH) has been highlighted as an important part in future carbon neutral energy supply. However, the performance of different DH systems varies a lot and the existing regulations do not always motivate DH companies to move toward more sustainable heat production. Therefore, this article presents novel methodology for Climate index determination which can be further used for the comparison of DH systems. The Climate index includes seven different indicators which show DH system performance according to energy efficiency, sustainability and environmental impact dimensions. The methodology is applied for 20 different DH systems operating in Latvia. The results show that the performance of 5 natural gas-based DH systems is below the determined climate benchmark.
\end{abstract}

Keywords - Benchmarking; district heating; energy efficiency; sustainable heat supply.

\section{INTRODUCTION}

There are several aspects affecting the efficiency of the DH companies' heating generation and heat tariff [1]. One of most important is the district heating (DH) regulation mechanism. Limited or non-existing competition that is commonly seen in the natural monopolies of utilities, including the district heating production market, create additional challenges for the regulator when it comes to operational efficiency evaluation. The lack of competition does not incentivize DH producers to increase the productivity of their production processes and the integrity of tariff determination [2].

Compared to a strictly regulated DH market, in a fully liberalized DH environment, the tariff is determined based on the DH performance benchmarking parameters [1], [2]. It promotes an incentive-based regulation framework [3], [4]. While a strong debate over which of the DH regimes is the most convenient [5]-[8] is on-going, more and more studies focus on the examination of the effects and benefits of introducing benchmarks in DH market regulation for the operational efficiency evaluation [9], [10]. Benchmarking in a natural monopoly market structure is as useful as in a fully liberalized market since it allows to compare how the performance efficiency of DH production companies differ even though the same service is provided for the end-consumer [2].

A study by Marques et al. [11] concludes that the application of benchmarking for companies operating in the utilities and in a natural monopoly market structure has several advantages. It incentivizes companies to operate more efficiently and implement innovative solutions to increase technical efficiency which results in the optimization of operations and

* Corresponding author.

E-mail address: ieva.pakere@ rtu.lv

C2020 Ieva Pakere, Dace Lauka, Kristiāna Dolge, Valdis Vitolins, Ilze Polikarpova, Stefan Holler, Dagnija Blumberga. 
capital expenses, increased return on investment, and improved information transparency to the utility consumers and stakeholders [11].

The findings from previous studies conclude that DH providers and their systems differ considerably, therefore empirical regression analysis might not be sufficient to obtain valuable results [12]. Instead, the model should incorporate different explanatory parameters and relative indicator values that would rank each DH company with respect to its distance from the benchmark [12]. However, there is still no consensus among researches on the application of most appropriate benchmarking technique, since it has been found that the choice of the benchmarking methodological approach, including indicators and model boundaries influence the identified efficiency performance scores and ranking of the DH companies [13], [14].

There are studies that introduce benchmark-based models as tools to measure DH efficiency [9], [10]. A benchmark model includes a combination of different technical, structural, economic indicators such as fuel type and prices, regulations in force, heat load and system capacity, heat generation and transmission efficiency and others [15]. In addition, when evaluating economic and environmental efficiency of DH plants, governmental decision making, market structure, and managerial performance indicators are included [9].

Type of fuel consumed is a significant indicator that is incorporated in DH benchmark setting studies. The share of renewable energy resources (RES) used in DH systems measure the overall sustainability of the existing DH since it strongly affects the amount of greenhouse gas emissions produced [10]. Setting an appropriate benchmark allows to group DH companies not only with respect to their heat generation efficiency but by their achievement towards low-carbon system incorporation as well. Therefore, it allows to highlight those DH companies that reflect values below the determined benchmark. As a result, restructuration and system improvement activities might be suggested to move towards more sustainable low-carbon DH operation models [10]. In fact, environmental goals are found to be among the dominant long-term operational targets of DH producers [16] since more sustainable production is encouraged from the side of both the regulatory body and the consumer.

District heating plays a key role in achieving ambitious global climate change mitigation goals [17], [18], therefore it is necessary for the authorities to design instruments and introduce benchmarks that would monitor and stimulate $\mathrm{DH}$ providers to reduce their greenhouse gas emissions. Decarbonization of DH providers can be achieved by utilizing more efficient technologies or using less polluting energy sources, therefore moving closer towards fully implementing a renewable, sustainable, carbon-free DH system [19].

Energy efficiency is one of the most significant factors for both reduction of climate change and the DH tariff [20]-[22]. Energy efficiency in DH can be increased by adapting renewable energy resources [23] and by improving technological efficiency of heat generation and distribution networks [24]. Therefore, indicators measuring the performance of DH technical parameters should be incorporated within the DH evaluation benchmark-based models.

In terms of technological parameters, type of heat source (boiler houses or CHP) should be considered when analysing DH performance indicators [10]. Moreover, the technological condition of the boiler houses and CHP strongly affect the generated heat efficiency, therefore, DH benchmarking studies suggest to integrate variables that consider the investments made in the heat source reconstruction activities in the recent years of their operating activity [10]. In fact, it is especially important for the DH infrastructure performance assessment in Eastern Europe where lack of investments in the past indicate that future DH modernization strategies must be implemented for future DH sustainability [22]. 
The empirical findings by Noussan conclude that the performance and efficiency of DH providers is strongly dependent on the energy source, fuel mix, conversion technologies, as well as on the network losses in the system [25]. Moreover, when analysing technical indicators in more detail, temperature is responsible for a large amount of network losses that have occurred. In order to maximize the efficiency of the DH system, the network losses should be reduced to a minimum. Therefore, low heat supply and return temperature in the heat distribution chain is crucial to increase the energy efficiency of DH networks [26].

Other technology related opportunities are emphasized in a study by Paiho \& Saastamoinen [8] as important factors for the long term development of DH system: the implementation of new production means, digitalization of operational processes and services. Diversification of the production means includes the utilization and implementation of solar, ground-source, surplus heat, geothermal energy, and other means that could potentially increase the long term energy efficiency and optimize costs for DH production companies [8].

A novel technological efficiency benchmarking parameter was introduced in the study by Sarma \& Bazbauers, [1], which demonstrate that in order to enhance the technological development and advancement in the DH infrastructure, 'best available technology' (BAT) indicators could be used to set a benchmark that would serve as an instrument to monitor the achievements towards higher efficiency of DH companies [1]. By setting the efficiency requirements based on BAT indicators, DH companies could be stimulated and guided towards improving their efficiency [1]. BAT parameters for different DH elements could be used to construct the benchmark indices that would indicate how DH plant's energy efficiency deviates from the energy savings that BAT technologies can offer [27].

Another significant DH performance efficiency parameter is the amount of energy generated. If the total produced energy output increases, the $\mathrm{DH}$ system benefits from economies of scale [28] where the total costs per one unit of generated energy decreases [29] and therefore the system operates with higher economic efficiency and could provide a competitive heating tariff to the consumer. The cost optimization that the economies of scale bring to the DH system increases the overall efficiency and competitiveness of DH. Therefore, the mergers of DH companies and the overall expansion of DH business is suggested [30].

The main aim of this particular research is to present a novel methodology for Climate index determination which can be further used for the comparison of DH systems. The Climate index includes seven different indicators which show DH system performance according to energy efficiency, sustainability and environmental impact dimensions. The methodology is elaborated for Latvia, but it can be used in other countries, depending on the availability of data and national priorities in energy supply sector.

\section{Methodology}

The main steps for climate benchmark determination can be seen in Fig. 1. The availability of statistical overviews for main DH operators is limited, therefore, it is necessary to combine different data sources. The reviews of environmental statistics (in particular, overview of air protection) coordinated by State limited Liability Company 'Latvian Environment, Geology and Meteorology Centre' are used to determine the fuel consumption for heat production [31]. The produced and consumed heat can be seen in applications from approvals of the heat energy tariff by the Public Utilities Commission (PUC) [32]. The power produced in CHP is obtained from the amounts paid within the framework of mandatory procurement (feed-in tariff) [33], but for the missing information annual reports of companies are used. Authors use the data set from $20 \mathrm{DH}$ companies. 


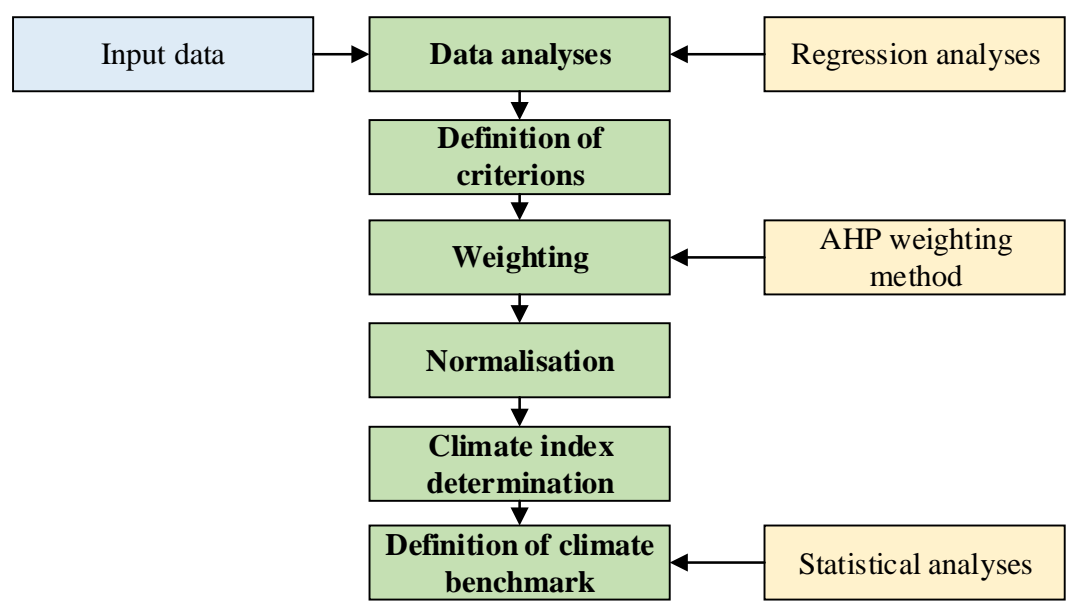

Fig. 1. Main steps and methods for determination of climate benchmark.

After the detailed data assessment, authors define the main criteria for further analyses. Seven different criteria are used (see Fig. 2) for calculation of the Climate index in the particular case study. However, the criteria can be adjusted for country specific conditions. The criteria are grouped within three different categories to have a more comprehensive overview of $\mathrm{DH}$ system performance. Some of the selected criteria are interrelated, for example, the total $\mathrm{CO}_{2}$ emissions and primary energy factor depend on heat losses and share of RES. However, each of chosen criteria show different aspects related to heat generation and transmission operation conditions. The further weighting step allows to take into account the interrelation by applying higher or lower weight score for particular criterion.

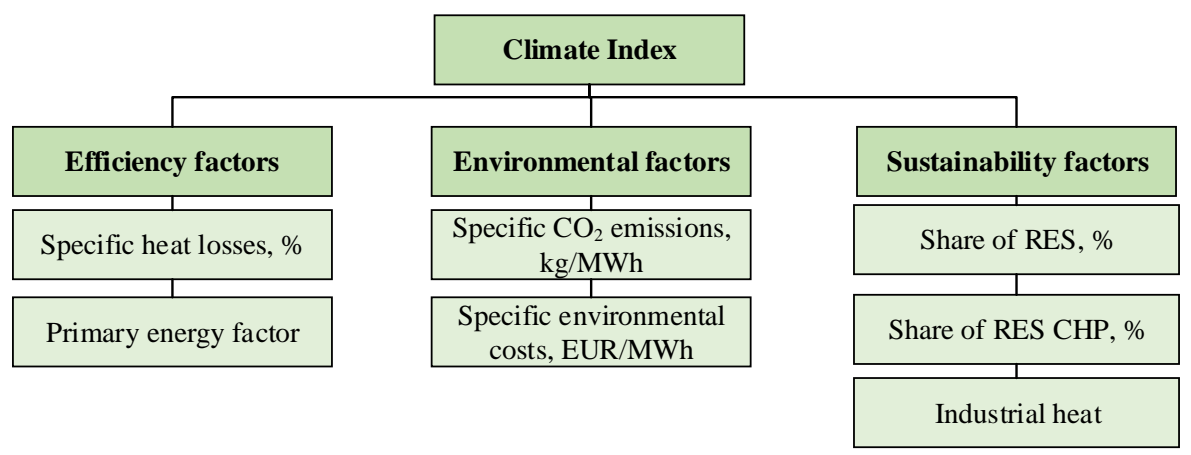

Fig. 2. Criteria merged within the Climate index.

The analysed efficiency factors are the transmission heat losses from the heating network identified as a percentage of total produced heat and the primary energy factor. Primary energy factor (PEF) is an energy indicator used for quantifying the primary energy use of a plant defined according to Eq. (1). 


$$
P E F=\frac{\sum_{j} E_{j} \cdot f_{\mathrm{p}, j}-E_{\mathrm{CHP}} \cdot f_{\mathrm{p}, \mathrm{el}}}{E_{\mathrm{del}}}
$$

where

$E_{j} \quad$ the amount of the $j$-th primary energy consumed;

$E_{\mathrm{CHP}}$ the amount of electricity produced in the CHP if any is installed;

$f_{\mathrm{p}, j} \quad$ the primary energy factor related to an energy source;

$f_{\mathrm{p}, \mathrm{el}}$ the primary energy factor for the power plants;

$E_{\mathrm{del}}$ the amount of energy delivered to the consumers.

The used primary energy factors can be seen in Table 1 . Those are determined as country specific values and highly depends on the national electricity mix. The assumptions can be subject to change for assessment in other countries.

Authors have identified two main environmental factors: the specific $\mathrm{CO}_{2}$ emissions and the specific environmental costs associated with different external costs related to heat production. The environmental cost factors have been identified according to previous studies [34] (see Table 1).

In addition, sustainability criteria are used to evaluate the used energy production technologies and energy sources. Therefore, authors have identified three different criteria: the share of RES, the share of heat produced in RES CHP and the share of heat purchased from industrial enterprises. It should be noted, that the heat purchased from different energy production utilities is not perceived as heat from an industrial object. The heat from industrial enterprises could be attributed to industrial waste heat and other excess heat sources when such energy sources occur.

TABle 1. Main Assumptions for CALCUlation OF CRITERIA

\begin{tabular}{lc}
\hline & Primary energy factors \\
\hline Fossil fuels & 1.1 \\
Biogas & 0.5 \\
Biomass & 0.2 \\
Power from the grid & 1.5 \\
\hline \multicolumn{2}{c}{ Environmental costs, EUR/MWh } \\
\hline CHP Biomass & 4.3 \\
CHP Natural gas & 11.7 \\
CHP Coal & 24.1 \\
CHP Biogas & 13.8 \\
HOB Natural gas & 17.9 \\
HOB Biomass & 11.2 \\
\hline & $\mathbf{C O}_{\mathbf{2}}$ emission factors, $\mathbf{~ k g / M W h}$ \\
\hline Diesel fuel & 267 \\
Natural gas & 202 \\
Coal & 354 \\
\hline
\end{tabular}


The criteria are prioritized to better reflect the use of sustainable development opportunities. The weights for each criterion are calculated according to the Analytic Hierarchy Process method (AHP). The base of the method is a pairwise comparison matrix, which reflects the relative importance of the criteria [35]. In this case, the evaluation was carried out by a group of experts, but a more comprehensive assessment could be provided by the involvement of various stakeholders in the weighting process. The obtained values of the criteria can be seen in Fig. 3. The highest priority has been determined for specific heat losses and the share of industrial heat.

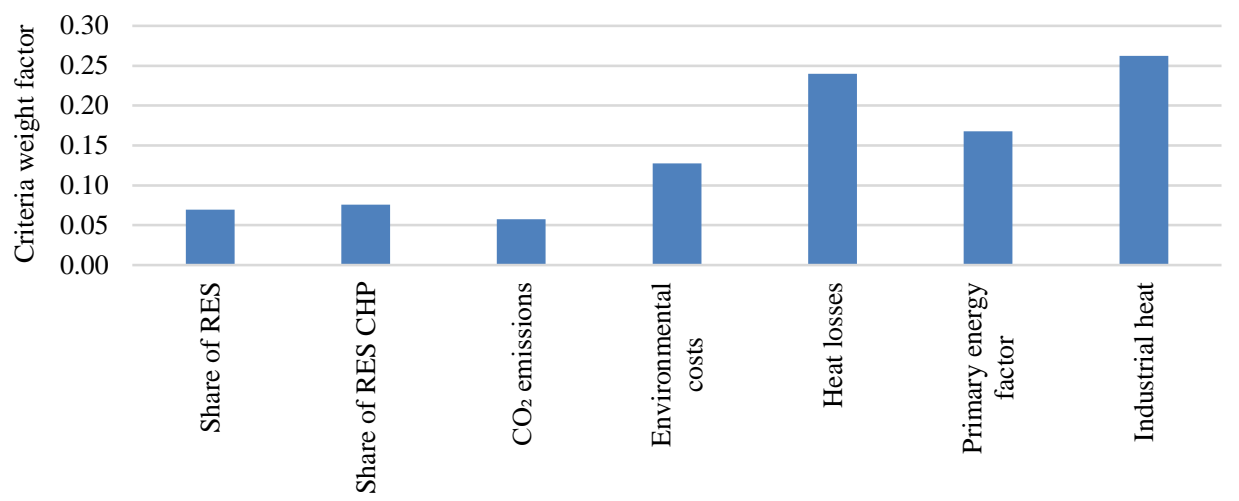

Fig. 3. Obtained weights for each criterion.

The calculated criterion $j$ has been normalized by using Weitendorf's linear normalization method [36]. Eq. (2) is used if the optimal indicator value needs to be maximized and Eq. (3) is used if the desirable indicator value is minimal.

$$
\begin{aligned}
& b_{i j}=\frac{x_{i j}-\min x_{i j}}{\max x_{i j}-\min x_{i j}} \\
& b_{i j}=\frac{\max x_{i j}-x_{i j}}{\max x_{i j}-\min x_{i j}}
\end{aligned}
$$

The normalized and weighted values of the criteria are summed to obtain the Climate index for each DH operator. Further, the authors use statistical analyses and the Pareto principle to determine the Climate benchmark for the particular set of DH operators.

\section{RESUlts}

Authors have analysed the performance of $20 \mathrm{DH}$ operators in 2017 according to the methodology described above. The analysed DH systems differ a lot. The produced amount of annual heat ranges from more than $500 \mathrm{GWh}$ in the capital city of Latvia, Riga to less than $1 \mathrm{GWh}$ in smaller towns. The heat is produced both in heat only boilers (HOB) and CHP by using different energy sources as showed in Fig. 4. 


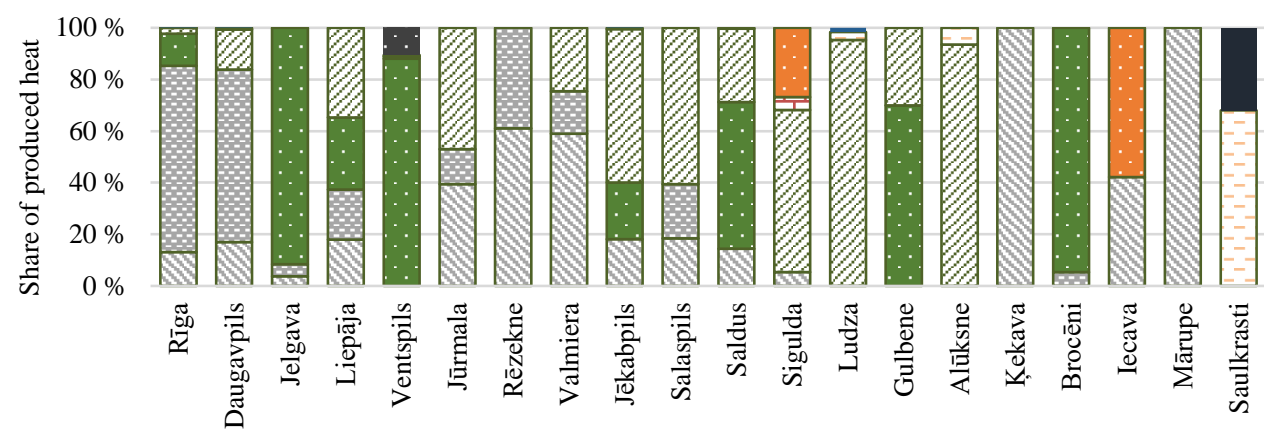

曰Natural gas HOB $\quad$ Natural gas CHP $\quad$ Wood chips CHP $\quad$ Wood chips HOB $\quad$ Wood pellets HOB

घFire wood HOB $\quad$ Fuel oil HOB $\quad$. Coal CHP $\square$ Biogas CHP $\quad$ Coal HOB

Fig. 4. Heat production technologies and energy sources used in analysed DH systems.

As can be seen in Fig. 4, there are DH systems that are already carbon neutral due to the use of biomass for heat production. However, the principles of sustainable development and biotechnology should be considered and the bio resource should be used efficiently. The heat production from biomass is not always the most sustainable solution.

The data analyses have been performed in order to determine the main impacting factors of the heat tariff. The regression analyses show an insufficient correlation between the determined criteria and final heat tariff which is in line with the conclusions of previous research [12]. The example of regression analyses for produced amount of heat and fuel costs is presented in Fig. 5. Even though the final heat tariff does not show a strong dependence of the total fuel costs (see Fig. 5), the fuel cost share is much higher in the total heat tariff in cases when natural gas is used as the main energy source (see Fig. 6).
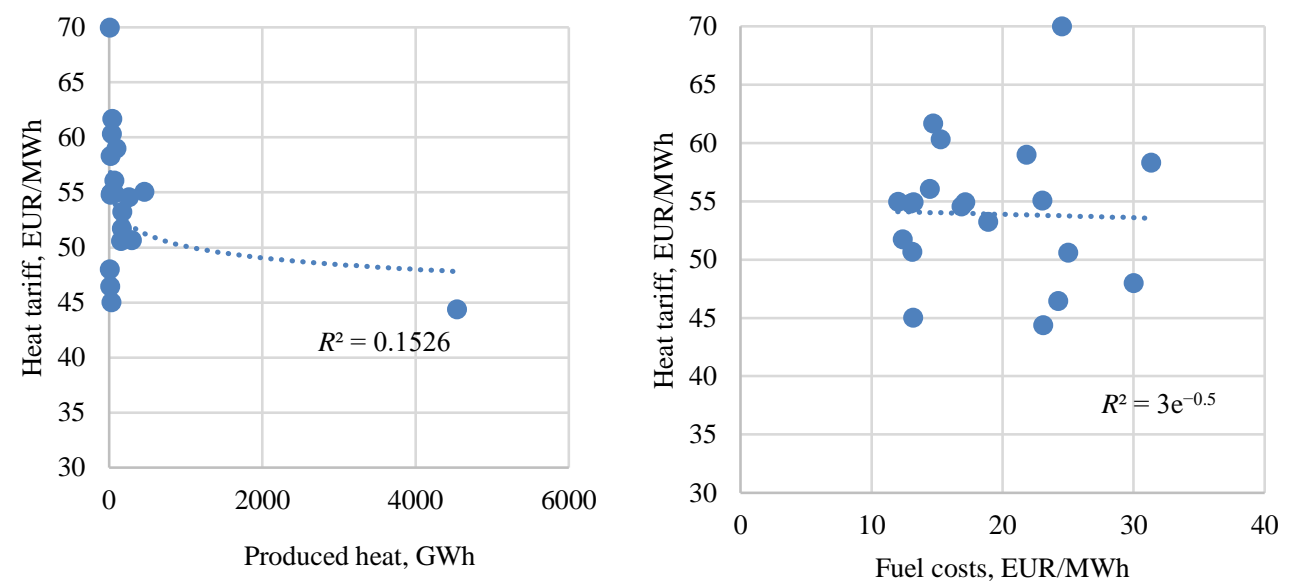

Fig. 5. Regression analyses results for different criteria. 


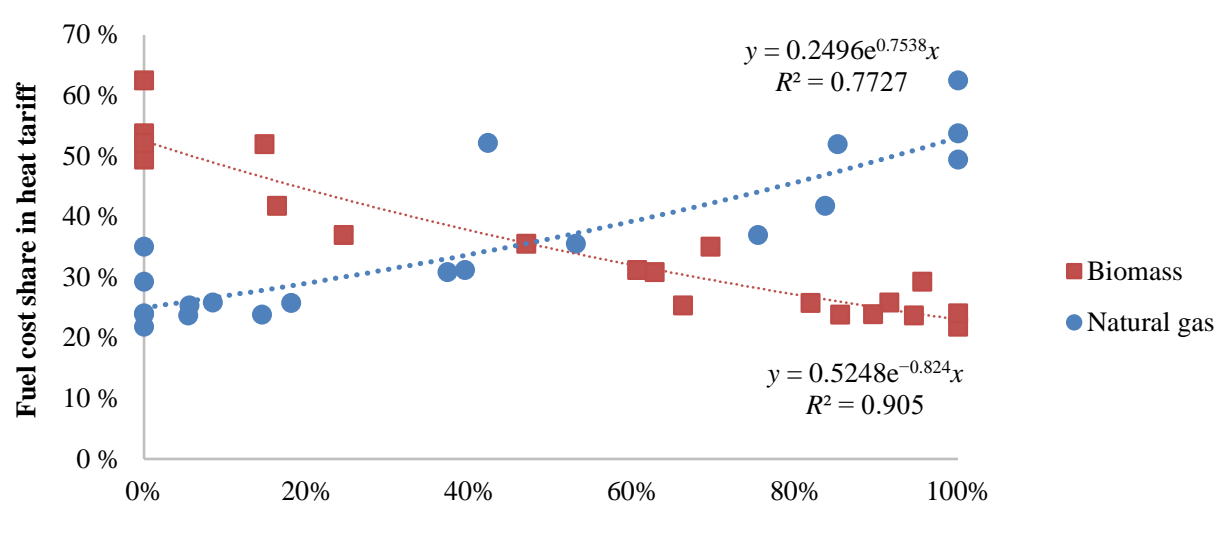

Fuel share

Fig. 6. Fuel cost share in heat tariff dependence on natural gas and biomass share in heat production.

Fig. 6 shows a good correlation between the fuel cost share in heat tariff and total biomass and natural gas share in overall DH energy balance. When biomass is used as an energy source, the fuel cost share decreases and there is an increase in other costs. One of analysed DH systems is further from determined biomass trend line because of use of wood pellets, which is more expensive than other biomass energy sources.

Table 2 shows the overview of normalized values of each criterion for analysed DH systems. The value 1 indicates the best ranked system, but the value 0 the lowest obtained value. As it can be seen, only two DH systems have purchased heat from industrial enterprises.

Fig. 7 shows the results of obtained Climate index values with and without application of criterion weights. As it can be seen, the application of weights has a small impact on the DH systems with highest and lowest Climate index values. The highest rank is obtained for the DH systems were the heat is produced by using a biomass CHP technology or the heat is purchased from industrial enterprises. The lowest Climate index values are for DH systems where natural gas is the main energy source for heat production.

TABle 2. NORMALISEd VALUES OF OBTAINED VALUES OF CRITERIA

\begin{tabular}{lccccccc}
\hline $\begin{array}{c}\text { DH } \\
\text { location }\end{array}$ & RES & $\begin{array}{c}\text { RES } \\
\text { CHP }\end{array}$ & $\begin{array}{c}\mathbf{C O}_{2} \\
\text { emissions }\end{array}$ & $\begin{array}{c}\text { Environmental } \\
\text { costs }\end{array}$ & $\begin{array}{c}\text { Heat } \\
\text { losses }\end{array}$ & PEF & $\begin{array}{c}\text { Industrial } \\
\text { heat }\end{array}$ \\
\hline Rīga & 0.15 & 0.13 & 0.19 & 0.48 & 0.57 & 0.95 & 0.00 \\
Daugavpils & 0.16 & 0.00 & 0.09 & 0.40 & 0.09 & 0.49 & 0.00 \\
Jelgava & 0.92 & 0.97 & 0.36 & 0.97 & 0.42 & 0.95 & 0.00 \\
Liepāja & 0.63 & 0.30 & 0.81 & 0.56 & 0.30 & 0.81 & 0.00 \\
Ventspils & 0.90 & 0.93 & 0.90 & 0.87 & 0.53 & 0.92 & 0.00 \\
Jūrmala & 0.47 & 0.00 & 0.21 & 0.30 & 0.00 & 0.55 & 0.00 \\
Rēzekne & 0.00 & 0.00 & 0.47 & 0.18 & 0.26 & 0.42 & 0.00 \\
Valmiera & 0.25 & 0.00 & 0.00 & 0.20 & 0.66 & 0.56 & 0.46 \\
Jēkabpils & 0.82 & 0.23 & 0.83 & 0.53 & 0.56 & 0.86 & 1.00 \\
Salaspils & 0.61 & 0.00 & 0.35 & 0.41 & 0.69 & 0.78 & 0.00 \\
Saldus & 0.86 & 0.60 & 0.80 & 0.73 & 0.08 & 0.86 & 0.00 \\
\hline
\end{tabular}




\begin{tabular}{llllllll}
\hline Sigulda & 0.94 & 0.30 & 0.95 & 0.42 & 0.39 & 0.87 & 0.00 \\
Ludza & 0.96 & 0.00 & 1.00 & 0.50 & 0.50 & 0.98 & 0.00 \\
Gulbene & 1.00 & 0.74 & 1.00 & 0.87 & 0.09 & 0.99 & 0.00 \\
Alūksne & 1.00 & 0.00 & 1.00 & 0.51 & 0.41 & 1.00 & 0.00 \\
Kekava & 0.21 & 0.00 & 0.39 & 0.00 & 0.26 & 0.00 & 0.00 \\
Brocēni & 0.95 & 1.00 & 0.97 & 1.00 & 0.42 & 0.99 & 0.00 \\
Iecava & 0.58 & 0.61 & 0.39 & 0.18 & 1.00 & 0.57 & 0.00 \\
Mārupe & 0.00 & 0.00 & 0.39 & 0.00 & 0.74 & 0.24 & 0.00 \\
Saulkrasti & 0.70 & 0.00 & 0.67 & 0.21 & 0.44 & 0.75 & 0.00 \\
\hline
\end{tabular}

For the particular analyses, the benchmark is obtained according to the Pareto principle by analysing the frequency of particular obtained Climate index values. The benchmark is determined as the most frequent minimal value of the index. In order to demonstrate sustainable heat production, the Climate index value should be above the determined benchmark value, which is 0.31 for this particular case study. The analyses show that five DH systems are below the obtained benchmark. Further methodology could be developed for the use of Climate index as one of criteria for heat tariff determination. Thus, the DH Companies with lowest Climate index values would be forced to move toward more sustainable heat production technologies.

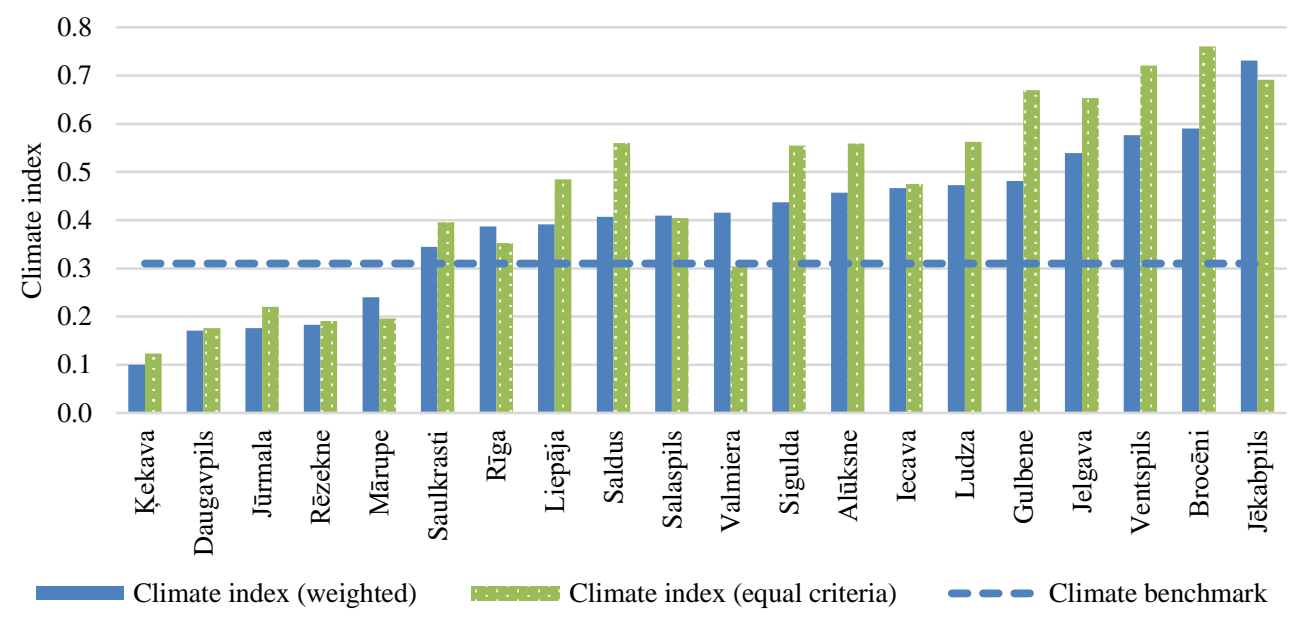

Fig. 7. Results of ranked Climate index values and obtained climate benchmark.

The determined Climate index has a potential for further development and use in system performance evaluation at international level. The methodology can be adjusted for particular country specific conditions by using additional technical, economic and environmental indicators. 


\section{Conclusion}

The Climate index has been introduced as a common indicator to evaluate the performance of DH system efficiency, environmental impact and sustainability. Seven different criteria are used for the evaluation: share of RES, share of RES CHP, specific $\mathrm{CO}_{2}$ emissions, environmental costs, specific heat losses, primary energy factor and share of heat delivered by industrial enterprises. The criteria are prioritized and weighted according to the AHP method.

The method is applied for 20 different DH operators. The obtained Climate index values for $15 \mathrm{DH}$ Companies are above the estimated benchmark for this particular study. Five DH systems were below the determined benchmark due to use of natural gas as the main energy source.

The use of a Climate index could improve the competition among DH operators and promote moving toward more sustainable solutions. The determined Climate index could be a criterion for the heat tariff calculation. DH Companies with highest Climate index could be allowed to have a higher profit share or easier heat tariff approval process.

The methodology can be adjusted and applied for different countries by including other criteria for evaluation. The national heat production objectives can be included through criteria weighting (e.g., lowering of transmission heat losses, integration of waste heat etc.).

Further analyses could include comparison of annual changes of Climate index values, as there are important improvements in DH system operation in recent years. Currently, the collection of necessary input data for Climate index calculations is time consuming. Therefore, the improvements in statistical data availability should be ensured in order to facilitate the calculation of the Climate index.

\section{ACKNOWLEDGEMENT}

This work has been supported by the State Research Program (VPP) project "Development of heat supply and cooling systems in Latvia" (project No. VPP-EM-EE-2018/1-0002).

\section{REFERENCES}

[1] Sarma U., Bazbauers G. Algorithm for calculation of district heating tariff benchmark. Energy Procedia 2017:128:445452. https://doi.org/10.1016/j.egypro.2017.09.029

[2] Munksgaard J., Pade L. L., Fristrup P. Efficiency gains in Danish district heating. Is there anything to learn from benchmarking? Energy Policy 2005:33(15):1986-1997. https://doi.org/10.1016/j.enpol.2004.03.019

[3] Comnes L. J., Stoft G.A., Greene S., Hill N. Performance-Based Ratemaking for Electric Utilities: Review of Plans and Analysis of Economic and Resource- Planning Issues Volume I. LBNL, Berkeley, 1995. [Online]. [Accessed 31.03.2020]. Available: https://emp.lbl.gov/publications/performance-based-ratemaking-electric

[4] Bogetoft P. Incentive Efficient Production Frontiers: An Agency Perspective on DEA. Managing Science 1994:40(8):959-968. https://doi.org/10.1287/mnsc.40.8.959

[5] Magnusson D. Who brings the heat? - From municipal to diversified ownership in the Swedish district heating market post-liberalization. Energy Research \& Social Science 2016:22:198-209. https://doi.org/10.1016/j.erss.2016.10.004

[6] Toke D., Fragaki A. Do liberalised electricity markets help or hinder CHP and district heating? The case of the UK. Energy Policy 2008:36(4):1448-1456. https://doi.org/10.1016/j.enpol.2007.12.021

[7] Tsybina E., Moreno-Cruz J., Tereshin A. Liberalisation lowers primary energy efficiency: Evidence from twin power systems. Energy 2019:173:423-435. https://doi.org/10.1016/j.energy.2019.02.004

[8] Paiho S., Saastamoinen H. How to develop district heating in Finland? Energy Policy 2018:122:668-676. https://doi.org/10.1016/j.enpol.2018.08.025

[9] Agrell P. J., Bogetoft P. Economic and environmental efficiencey of district heating plants. Energy Policy 2005:33(10):1351-1362. https://doi.org/10.1016/j.enpol.2003.12.011 
[10] Ziemele J., Vigants G., Vitolins V., Blumberga D., Veidenbergs I. District heating systems performance analyses. Heat energy tariff. Environmental and Climate Technologies 2014:13(1):32-43. https://doi.org/10.2478/rtuect-2014-0005

[11] Marques R. C., Simões P., Pires J. S. Performance benchmarking in utility regulation: The worldwide experience. Polish Journal of Environmental Studies 2011:20:125-132.

[12] Sarma U., Bazbauers G. District Heating Tariff Component Analysis for Tariff Benchmarking Model. Energy Procedia 2017:113:104-110. https://doi.org/10.1016/j.egypro.2017.04.029

[13] Jamasb T., Pollitt M. International benchmarking and regulation: An application to European electricity distribution utilities. Energy Policy 2003:31(15):1609-1622. https://doi.org/10.1016/S0301-4215(02)00226-4

[14] Hrovatin N., Zorić J. International Benchmarking of Electricity Tariffs. Enterp. Transit. Int. Conf. Proc. 2005:15:8398. [Online]. [Accessed 31.03.2020]. Available: http://www.eskom.co.za/CustomerCare/MYPD3/Documents/Interna tional_Tariff_Benchmarking_Report_270512.pdf

[15] Sarma U., Bazbauers G. District Heating Regulation: Parameters for the Benchmarking Model. Energy Procedia 2016:95:401-407. https://doi.org/10.1016/j.egypro.2016.09.046

[16] Åberg M., Fälting L., Forssell A. Is Swedish district heating operating on an integrated market? - Differences in pricing, price convergence, and marketing strategy between public and private district heating companies. Energy Policy 2016:90:222-232. https://doi.org/10.1016/j.enpol.2015.12.030

[17] Connolly D. et al. Heat roadmap Europe: Combining district heating with heat savings to decarbonise the EU energy system. Energy Policy 2014:65:475-489. https://doi.org/10.1016/j.enpol.2013.10.035

[18] Büchele R., Kranzl L., Hummel M. What is the impact of the policy framework on the future of district heating in Eastern European countries? The case of Brasov. Energy Strategy Reviews 2018:19:72-75. https://doi.org/10.1016/j.esr.2017.12.003

[19] Hast A., Syri S., Lekavičius V., \& Galinis A. District heating in cities as a part of low-carbon energy system. Energy 2018:152:627-639. https://doi.org/10.1016/j.energy.2018.03.156

[20] Difs K., Trygg L. Pricing district heating by marginal cost. Energy Policy 2009:37(2):606-616. https://doi.org/10.1016/j.enpol.2008.10.003

[21] Stennikov V., Penkovskii A. The pricing methods on the monopoly district heating market. Energy Reports 2020:6(S2):187-193. https://doi.org/10.1016/j.egyr.2019.11.061

[22] Poputoaia D., Bouzarovski S. Regulating district heating in Romania: Legislative challenges and energy efficiency barriers. Energy Policy 2010:38(7):3820-3829. https://doi.org/10.1016/j.enpol.2010.03.002

[23] Ristimäki M., Säynäjoki A., Heinonen J., Junnila S. Combining life cycle costing and life cycle assessment for an analysis of a new residential district energy system design. Energy 2013:63:168-179. https://doi.org/10.1016/j.energy.2013.10.030

[24] Dalla Rosa A., Christensen J. E. Low-energy district heating in energy-efficient building areas. Energy 2011:36(12):6890-6899. https://doi.org/10.1016/j.energy.2011.10.001

[25] Noussan M. Performance indicators of District Heating Systems in Italy - Insights from a data analysis. Applied Thermal Engineering 2018:134:194-202. https://doi.org/10.1016/j.applthermaleng.2018.01.125

[26] Gong M., Werner S. An assessment of district heating research in China. Renewable Energy 2015:84:97-105. https://doi.org/10.1016/j.renene.2015.05.061

[27] Badami M., Gerboni R., A. Portoraro. Determination and assessment of indices for the energy performance of district heating with cogeneration plants. Energy 2017:127:697-703. https://doi.org/10.1016/j.energy.2017.03.136

[28] Grundahl L., Nielsen S., Lund H., Möller B. Comparison of district heating expansion potential based on consumereconomy or socio-economy. Energy 2016:115(P3):1771-1778. https://doi.org/10.1016/j.energy.2016.05.094

[29] Wang Z. Heat pumps with district heating for the UK's domestic heating: Individual versus district level. Energy Procedia 2018:149:354-362. https://doi.org/10.1016/j.egypro.2018.08.199

[30] Park S. Y., Lee K. S., Yoo S. H. Economies of scale in the Korean district heating system: A variable cost function approach. Energy Policy 2016:88:197-203. https://doi.org/10.1016/j.enpol.2015.10.026

[31] Latvian Environment, Geology and Meteorology Centre database on environmental pollution [Online]. [Accessed 31.03.2020]. Available: https://www.meteo.lv/lapas/vide/parskatu-ievadisana/parskatu-ievadisana?id=1039\&nid=376

[32] The Public Utilities Commission (PUC) or the Regulator. Approved energy tariffs [Online]. [Accessed 31.03.2020]. Available: https://www.sprk.gov.lv/index.php/content/iesniegtie-tarifu-projekti

[33] Ministry of Economics. Information on issued decisions on mandatory electricity procurement. [Online]. [Accessed 31.03.2020]. Available: https://em.gov.lv/lv/nozares_politika/atjaunojama_energija_un_kogeneracija/informacija_par _izdotajiem_lemumiem_par_elektroenergijas_obligato_iepirkumu/

[34] Alberici S., Boeve S., Breevoort P. et.al. Subsidies and costs of EU energy. An interim report, 2014. [Online]. [Accessed 31.03.2020]. Available: https://ec.europa.eu/energy/sites/ener/files/documents/ECOFYS\%202014\%20Sub sidies\%20and\%20costs\%20of\%20EU\%20energy_11_Nov.pdf

[35] Dynova L., Sevastjanov P., Tikhonenko A. A direct Interval Extension of TOPSIS Method. Expert Systems with Applications 2013:40(12):4841-4847. https://doi.org/10.1016/j.eswa.2013.02.022

[36] Turski F., Edmundas Z., Peldschus K. Multi-criteria Optimization System for Decision Making in Construction Design and Management. Engineering Economics 2009:1(61):7-17. 


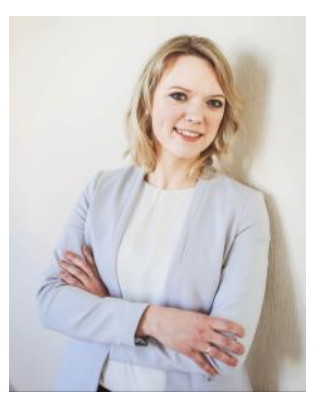

Ieva Pakere, M. sc. ing., researcher. Main research areas are district heating optimisation, solar thermal and power systems, mathematical modelling, RES and energy efficiency improvement of technological processes. She has more than 20 scientific publications indexed by SCOPUS database and h-index 6 .

E-mail: Ieva.Pakere@rtu.lv

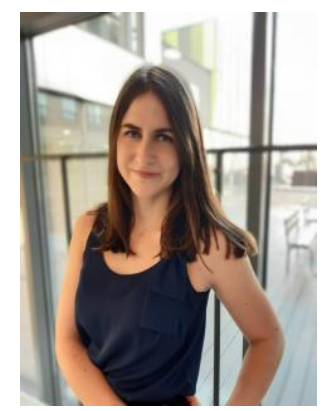

Kristiāna Dolge, M. sc. ing. student, research assistant. Main research areas are evaluation of energy efficiency potential, sectorial comparisons, industrial energy efficiency, development of composite indices, index methodology application for bioeconomy and RES sustainability assessment.

E-mail: Kristiana.Dolge@rtu.lv

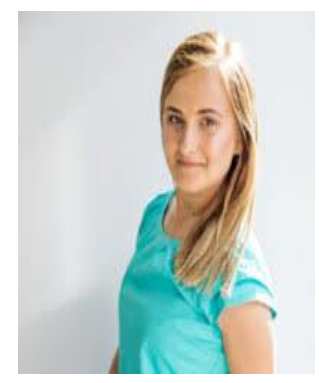

Ilze Poḷikrpova, M. sc. She is a PhD student at Riga Technical University. Main research areas are district heating, solar thermal and RES technologies. Author has two publications in SCOPUS database.

E-mail: ilze.polikarpova@gmail.com

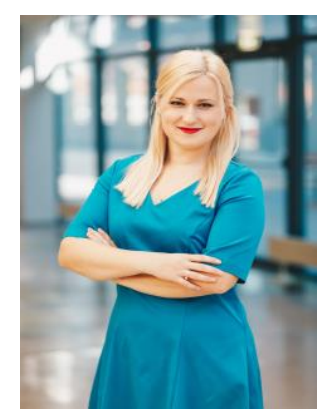

Dace Lauka, Dr. sc. ing., RTU IESE senior researcher, docent. In August 2018, defended the doctoral thesis on the sustainable use of renewable energy resources. She has a Master's degree in Environmental Engineering, graduating from both RTU and VGTU. Since the start of her Master's degree studies she has been involved in research related to sustainable use of resources, renewable energy resources, environmental technologies, district heating and cooling systems. She is an author and co-author of 27 scientific publications published in the Scopus database, with total quotation 146. She co-authored 4 scientific monographs and received 3 patent applications. The h-index is 7 . She is able to justify her scientific work by participating in scientific conferences of various scales and carrying out scientific projects. E-mail: Dace.Lauka@rtu.lv 

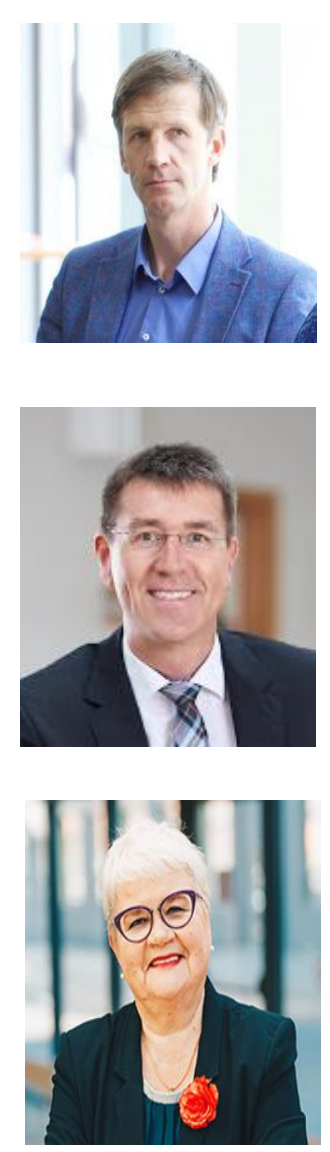

Valdis Vitolins, Dr. Sc. Ing. in Optimisation of District Heating System Operation with Biofuel Energy Source, Riga Technical University, Institute of Energy Systems and Environment. Research interests: district heating, renewable energy resources, energy efficiency, climate technologies. He is a member of Association of District Heating of Latvia, has Certificate of Design and Supervision of HVAC systems in Association Heating, Water and Gas engineers of Latvia. Valdis Vitolins has been working in Ministry of Economics of Republic of Latvia, Ministers bureau as Advisor on energy sector and now is member of the board in Ltd. "Jurmalas siltums" and leading researcher in Riga Technical University, Institute of Energy Systems and Environment.

E-mail: Valdis.Vitolins@rtu.lv

Stefan Holler, Dr. ing., works as a professor for energy and environmental technology at HAWK University of Applied Sciences and Arts, Germany where he has been teaching and researching since 2014. He is director of Sustainable Energy and Environmental Technology research group. Research interests are related to environmental management, energy and environmental technology. His research fields cover District Heating and Cooling, Combined Heat and Power and Renewable energy systems with a special focus on transformation and flexibility of energy systems. He avails of significant experience in the management of various national and international projects. Stefan Holler is vice chairman of the European Technology Platform for District Heating and Cooling, DHC+ since 2011 and member of the advisory board for climate protection in the City of Göttingen.

Dagnija Blumberga, Dr. habil. sc. ing. Professor, director of Institute of Energy Systems and Environment, Riga Technical University. She is an expert in bioeconomy, cleaner production, circular economy, renewable energy, climate change, biotechnologies and other environmental engineering themes. Author of more than 400 scientific publications. Hirsch index 20. She has an experience in international projects as project leader and expert. Member of Professor Council of Riga Technical University, Member of Professor Council Of university of Latvia.

E-mail: dagnija.blumberga@rtu.lv ORCID iD: https://orcid.org/0000-0002-9712-0804 